\title{
Hourly wages and working time in the Dutch market sector 1962-1995
}

Citation for published version (APA):

de Regt, E. R. (2004). Hourly wages and working time in the Dutch market sector 1962-1995. METEOR, Maastricht University School of Business and Economics. METEOR Research Memorandum No. 028 https://doi.org/10.26481/umamet.2004028

Document status and date:

Published: 01/01/2004

DOI:

10.26481/umamet.2004028

Document Version:

Publisher's PDF, also known as Version of record

\section{Please check the document version of this publication:}

- A submitted manuscript is the version of the article upon submission and before peer-review. There can be important differences between the submitted version and the official published version of record.

People interested in the research are advised to contact the author for the final version of the publication, or visit the DOI to the publisher's website.

- The final author version and the galley proof are versions of the publication after peer review.

- The final published version features the final layout of the paper including the volume, issue and page numbers.

Link to publication

\footnotetext{
General rights rights.

- You may freely distribute the URL identifying the publication in the public portal. please follow below link for the End User Agreement:

www.umlib.nl/taverne-license

Take down policy

If you believe that this document breaches copyright please contact us at:

repository@maastrichtuniversity.nl

providing details and we will investigate your claim.
}

Copyright and moral rights for the publications made accessible in the public portal are retained by the authors and/or other copyright owners and it is a condition of accessing publications that users recognise and abide by the legal requirements associated with these

- Users may download and print one copy of any publication from the public portal for the purpose of private study or research.

- You may not further distribute the material or use it for any profit-making activity or commercial gain

If the publication is distributed under the terms of Article $25 \mathrm{fa}$ of the Dutch Copyright Act, indicated by the "Taverne" license above, 


\title{
Hourly wages and working time in the Dutch market sector 1962-1995
}

\author{
Erik R. de Regt \\ Maastricht University \\ Department of Economics \\ P.O. Box 616 \\ 6200 MD Maastricht \\ The Netherlands \\ tel: $+31-43-3883809$ \\ fax: +31-43-3884864 \\ email: e.deregt@algec.unimaas.nl
}

\begin{abstract}
This paper analyses the joint behaviour of hourly wages and standard hours in the Netherlands. With respect to the development of full-time hours to different hypotheses are suggested: worksharing or productivity-sharing. Under the work-sharing hypothesis, high unemployment would lead to reduced hours, whereas under productivity-sharing, increased productivity leads to higher wages or reduced hours. The evidence is in favour of the productivity hypothesis. There is no direct impact of unemployment on the evolution of hours. Moreover, although reduced hours tend to increase hourly wages in the short run, this is not the case in the long run.
\end{abstract}

JEL classification

Keywords
J22, J31

Work-sharing, hours worked, productivity, wages 


\section{Hourly wages and working time in the Dutch market sector 1962-1995}

\section{Introduction}

During the $20^{\text {th }}$ century there has been an impressive decline in annual working hours in capitalist countries. Nowadays full-time workers tend to work about 800 to 1000 hours less a year than their grandparents a few generations earlier. In some countries the bulk of the decline occurred during the first-half of the last century, in other countries the decline started later. In 1936, under Blum's Front Populaire, France was the first country to introduce the 40-hour week, for example. The New Deal policy of the 1930s in the United States also involved a reduction of working hours. These are two early examples of a so-called work-sharing strategy, i.e. redistributing work amongst people so as to reduce involuntary unemployment, Drèze (1986, p. 562).

After the Second World War during the period of reconstruction, working hours remained rather high in many European countries, whereas the 40-hour week was introduced in the USA. During the high growth period of the 1960s and early 1970s, however, working times were substantially reduced in (continental) European countries. So before the oil shocks of the 1970s, standard working times were fairly harmonised in Western industrialised countries, just as in the beginning of the century. The large reductions of working time during this post-war period, are probably examples of the process of allocating the gains of productivity growth between wage increases and increases in leisure time. I will call this phenomenon productivity-sharing, as opposed to the work-sharing argument presented above.

Since the oil shocks of the 1970s, full-time hours remained rather stable in the USA and the UK, but they dropped further in continental Europe. An important question is whether this decline was due to work-sharing or to productivity-sharing. In other words, was it a defensive strategy intended to reduce unemployment or was it just consuming part of the productivity gains in increased leisure.

The paper provides an answer for the Dutch market sector, where work-sharing was hotly debated between social partners, especially during the 1980s. To analyse the problem, a simple model of joint wage and hours determination is introduced. The model allows the identification of separate channels for productivity-sharing and work-sharing. To deal with the nonstationarity of the data, cointegration techniques are used, and the model is estimated in errorcorrection form. The evidence suggests that the full 600 hours reduction of full-time hours between 1960 and 1995 was the result of productivity-sharing, not of work-sharing.

Moreover, the results indicate that reduced hours did not increase hourly wage costs, at least in the long run. The typical Dutch wage equation is specified in annual terms, however, without a separate effect for hours worked, see Broer et al. (2000), Broersma and Den Butter (2002), Graafland and Huizinga (1999) or Muysken et al. (1999). That specification is rejected in my analysis: annual hours do have a separate role to play in wage equations.

The impact of reduced hours on wages has also been stressed in the work-sharing literature, see e.g. Hunt (1998) and Kapteyn et al. (2004) for recent overviews. The theoretical effect is ambiguous, but the empirical evidence seems to point in the direction of reduced hours increasing hourly wages, see Kapteyn et al. (2004). The analysis presented here suggests that although this effect occurs in the short run, it may disappear in the longer run. 
Only few papers include the determinants of standard hours worked in an empirical analysis. ${ }^{1}$ Exceptions are Jacobson and Ohlsson (2000) and Kapteyn et al. (2004), who estimate joint models of wages, hours and employment. Both papers report a small negative wage elasticity in their wage equation, suggesting that income effects of labour supply dominate. The evidence presented here indicates that beside labour supply factors, labour demand factors play a role in the determination of standard hours.

The paper is set out as follows. Section 2 provides some background for the Dutch market sector since 1960. Section 3 introduces some of the theoretical aspects of the work-sharing versus productivity-sharing debate, using a simple log-linear model for the behaviour of wages and working hours. Section 4 presents some properties of the data, showing that cointegrating relations exist. Section 5 provides the estimation results. The implications for the work-sharing or productivity-sharing debate are summarised in Section 6. Conclusions are drawn in the final section.

\section{Dutch working time developments ${ }^{2}$}

Figure 1 shows the development of normal full-time working hours in the Dutch market sector. The solid line corresponds to annual hours, whereas the dotted line represents weekly hours. The data do not incorporate overtime hours, neither do they correct for absenteeism. The empirical evidence suggests that actual hours follow standard hours quite closely, see Hunt (1999), Ilmakunnas (1995) and Kapteyn et al. (2004). During the fifties, annual working time $(H)$ decreased rather slowly from about 2350 hours to roughly 2300 hours. At that time a normal workweek consisted of 48 hours and employees had two to three weeks off per year, including public holidays. During the sixties and early seventies, weekly hours decreased gradually to reach the 40-hour week in 1975. At the same time some additional holidays were introduced, so that in the beginning of the seventies four weeks off became the norm. As a consequence of both developments, annual working time fell below 1900 hours in 1975. The average decrease in normal hours during this period until the oil shocks amounted to $1.2 \%$ per annum, see Table 1 , which presents some key indicators by sub-period.

\section{[FIGURE 1 ABOUT HERE]}

\section{[TABLE 1 ABOUT HERE]}

The whole period of the sixties and the first half of the seventies was characterised by low unemployment rates and strong productivity growth. Before the first oil crisis, the unemployment rate $(u)$ was on average over the period 1960-1973 only $1.1 \%$, and hourly productivity $\left(A_{h}\right)$ increased by $6.2 \%$ per year. The net hourly real consumer wage $\left(W_{n}\right)$ lagged slightly behind with a growth rate of $5.0 \%$, whereas gross hourly real producer wages $\left(W_{c}\right)$

\footnotetext{
${ }^{1}$ Sometimes a distinction is made between actual and standard hours. However, the empirical evidence surveyed in Kapteyn et al. (2004) suggests that actual working hours move (almost) proportionally with standard hours.

${ }^{2}$ For more extensive descriptions of the recent history of the Dutch labour market, see e.g. Broersma et al. (2000) or Hartog (1999). An account of the development of Dutch working time is given in De Neubourg (1991) and Van Doorne-Huiskes and De Lange (1994).
} 
increased by $7.5 \%$. The difference was mainly caused by the increasing tax wedge to finance the welfare state arrangements introduced during the sixties. As a consequence, the labour share in value added $\left(\varphi_{N}\right)$ increased substantially from $62 \%$ in 1960 to $82 \%$ in 1975 .

After the first oil shock in 1974, the Dutch economy was in disarray. Unemployment increased rapidly, reaching its highest level of about $10 \%$ in 1983. Simultaneously, the growth rate of hourly productivity dropped to only $3.2 \%$ in the period 1974-1982. Wage increases where roughly in line with productivity, but the labour share remained at a high level. The decrease in working time slowed down: 40-hours a week remained the norm, although the number of holidays increased slightly, reducing the number of weeks worked. In 1982 the labour market situation was considered to be dramatic, this lead to consultations between the government and the social partners. In October 1982 the famous Wassenaar Agreement was struck. One of the main recommendations was to moderate wage claims in exchange for increases in employment and reductions in working time.

With respect to wages, the impact of the Wassenaar Agreement can be seen from Table 1. Real hourly wages increased less than hourly productivity: whereas hourly productivity increased with $2.2 \%$ per year in the period 1983-1995, real hourly wage costs increased only by $1.3 \%$. As a consequence, the labour share fell with 10 percentage points. In terms of unemployment the results were less impressive, as unemployment remained rather high. However, the small decrease in 1995, has been followed by larger decreases during the second half of the 1990s.

After the Wassenaar Agreement, annual standard full-time working time fell from 1840 hours in 1982 to 1740 hours in 1992, see Figure 1. This decrease is partly due to a reduction of the normal workweek to 38.5 hours in the eighties. The second element is a further increase in the number of days off, amounting to almost seven weeks in 1995.

In summary, on average annual full-time working hours declined with $0.8 \%$ per year in the period 1960-1995. Part of this decline occurred during the golden sixties, but another part during the high unemployment era of the eighties. This suggests that both the productivitysharing - consuming productivity gains in leisure - and the work-sharing arguments - reducing hours in an attempt to redistribute unemployment - could be relevant.

As a first crude test, Table 2 presents Granger causality tests between working time $H$, hourly productivity $A_{h}$ and unemployment $u{ }^{3}$ The results indicate that working time is Granger caused by productivity, but not by unemployment. Moreover, productivity and unemployment do not seem to be Granger caused by full-time working hours. ${ }^{4}$ These results suggest that the decline in full-time working hours is most likely due to the productivity-sharing hypothesis. To analyse the underlying mechanisms in some more detail, however, the next sections develop and estimate a simple model.

[TABLE 2 ABOUT HERE]

\footnotetext{
${ }^{3}$ Except for the unemployment rate $u$, small letters denote natural logarithms of the corresponding variables.

${ }^{4}$ Similar results were obtained from a reduced form specification, omitting the contemporaneous exogenous variables as explanatory variables under the general specification.
} 


\section{Theoretical background}

From a theoretical point of view, the work-sharing strategy has been severely criticised. The major argument is the so-called lump-of-labour fallacy, see Layard et al. (1991, Ch. 10) and Kapteyn et al. (2004). This critique refutes the idea that there is a fixed amount of work that can be redistributed at will. On the contrary, employment and thus unemployment is determined by demand and supply factors, or in a more modern context by price and wage setting behaviour. Reductions in working time, may affect both price setting and wage setting, and the final impact on (un)employment is uncertain, see Freeman (1998), Hunt (1998), Kapteyn et al. (2004) and Marimon and Zilibotti (2000).

The contribution of this paper is to have a closer look into the origin of the observed reduced hours. The impact on unemployment will not be investigated. ${ }^{5}$ Two alternative hypotheses are typically suggested: the work-sharing hypothesis and what I labelled the productivity-sharing hypothesis. According to the work-sharing hypothesis reductions in hours may be due to high unemployment; whereas the productivity-sharing hypothesis indicates that productivity growth is the driving force. In the latter case, there may be a trade-off in wage determination between increased hourly remuneration and reductions in hours worked. The simplest model to capture both elements is a joint model of wage and hours determination.

\subsection{Wage determination}

In modern wage theories, wages are set, in one way or another, as a mark-up on the outside option, see Layard et al. (1991) for a well-known illustration. In the general equilibrium this leads to a wage curve, where wages depend negatively on the unemployment rate $u$. This curve may shift upward if aspiration levels, such as benefits or productivity, increase. Considering a simple log-linear specification, where except for the unemployment rate $u$ lowercase letters denote natural log's, this may be summarised for our purposes as

$$
w_{c}=\gamma_{0}-\gamma_{h} h+\gamma_{a} a_{h}+\gamma_{b} b-\gamma_{u} u+\gamma_{s} s+\gamma_{x}^{\prime} x_{w}
$$

where $w_{c}$ is the real hourly wage cost, $h$ is annual full-time hours worked, $a_{h}$ is hourly productivity, $b$ is net real level of unemployment benefits, $u$ is the unemployment rate, $s$ is the wedge between real producer wage costs $w_{c}$ and real net hourly consumer wages $w_{n}$, and finally $x_{w}$ summarises other wage push variables. In general the $\gamma$-parameters are expected to be positive.

As it stands, equation (1) includes the main determinants of Dutch wage equations, see for example Broer et al. (2000), Broersma and Den Butter (2002), Graafland and Huisinga (1999) and Muysken et al. (1999). First, capturing the aspiration level of workers, wages increase with productivity and with benefit levels. Typically, it is found that the effect is

\footnotetext{
${ }^{5}$ To do so, the model should be augmented with a labour demand or price setting equation. This is beyond the scope of this paper. Jacobson and Ohlsson (2000) and Kapteyn et al. (2004) include an employment equation in their analysis.
} 
proportionally, implying $\gamma_{a}=1-\gamma_{b}$. Second, as predicted in theory, higher unemployment reduces wages. Third, tax shifting is an important phenomenon in the Netherlands. ${ }^{6}$

Calmfors (1985) discusses the impact of working hours in a union monopoly framework. The impact of hours worked on hourly wages is indeterminate, with different factors operating in opposite directions. The impact is most likely to be U-shaped: for short hours reduced working times are likely to increase hourly wages; whereas for longer hours the opposite may be true. The sign conjectured in equation (1) illustrates the belief that the first case is nowadays most likely to occur. Moreover, as total remuneration is most likely to fall, $\gamma_{h}<1$ can be expected to hold.

Unfortunately, most empirical aggregate wage studies formulate their models in terms of annual wages $\left(w_{c}+h\right)$ and annual productivity $\left(a=a_{h}+h\right)$. The Dutch wage studies mentioned earlier are examples. This specification is just a special case of equation (1), with $\gamma_{h}=1-\gamma_{a}$. The only exception for the Netherlands I am aware of is Dur (2001). He finds an estimate of 0.77 for $\gamma_{h}$ indicating that a reduction in hours worked leads to an increase in hourly wages, although significantly less than proportional. However, as his wage equation contains the capital stock instead of labour productivity as an explanatory variable, it is hard to interpret this result. In their cross-country panel study Kapteyn et al. (2004) find a value of 0.40 for $\gamma_{h}$, with a standard error of 0.13 , suggesting that hourly wages increase, although less than proportionally. However, their productivity variable is GNP per capita (with an elasticity of 0.47 ). Rewriting this in terms of GNP per hour worked, as in equation (1), the implied coefficient for $\gamma_{h}$ is only -0.07 , suggesting an insignificant decrease in hourly wages.

\subsection{Hours determination}

Turning to the determinants of hours worked, the bulk of the literature focuses on labour supply models. Using a log-linear specification this would yield something like

$$
h^{s}=\alpha_{0}-\alpha_{w} w_{n}+\alpha_{x}^{\prime} x_{s}
$$

where $h^{s}$ is labour supply and $w_{n}\left(\equiv w_{c}-s\right)$ is the net real consumer wage. The vector $x_{s}$ captures other factors that may affect the individual labour supply decision, such as non-wage incomes, social norms, etc. To explain the downward trend in hours worked, these type of models have to assume that income effect dominates so that the labour supply curve is backward bending, implying $\alpha_{w}>0$ in equation (2). A problem with this approach is that most (cross-section) estimates of labour supply elasticities find small but non-negative wage elasticities, indicating $\alpha_{w}<0$. This is inconsistent with the observed secular decline in hours, unless the decline in hours is explained by factors in $x_{s}$.

The alternative explanation is that workers are constrained in their choice of working hours, as found for example by Dickens and Lundberg (1993), Osberg and Phipps (1993) and Tummers and Woittiez (1991). Union bargaining models including hours can explain this

\footnotetext{
${ }^{6}$ It sometimes is suggested that there is a difference between employer contributions and employee taxes, see Muysken et al. (1999). This difference is ignored in the present paper.
} 
phenomenon. The two extreme alternatives are on the one hand hours set by monopoly unions and on the other hand hours set by firms.

To start with the monopoly union case, Calmfors (1985) has shown that unions tend to demand working times $\left(h^{m}\right)$ that are shorter than considered optimal from the viewpoint of individuals $\left(h^{s}\right)$. The idea is that unions take into account the impact of hours worked on the demand for labour (i.e. the number of workers). Unions thus have an incentive to cut down hours to reduce the probability of unemployment. As the loss is lower if the outside option for union members is higher, union hours $h^{m}$ will increase with the benefit level and decrease with unemployment. The latter effect corresponds to the work-sharing hypothesis. Generalising the labour supply equation (2), union hours can be written as

$$
h^{m}=\alpha_{0}-\alpha_{w} w_{n}+\alpha_{b} b-\alpha_{u} u+\alpha_{x}^{\prime} x_{m}
$$

Unfortunately, the wage elasticity of union hours can not be signed a priori, although it can be argued that union hours are more likely to fall with net real wages than individual labour supply. The vector $x_{m}$ consists of the labour supply factors $x_{s}$, but also of factors related to the labour demand elasticity of the firm. As long as the labour demand elasticity is not affected by productivity increases, there is no direct role for the hourly productivity variable $a_{h}$, however. Nevertheless, equation (3) already incorporates elements of productivity-sharing hypothesis, but in the same indirect way as for the labour supply model: a permanent productivity shock affects the wages determined in equation (1), which in turn influence union hours. Accordingly, $\alpha_{w}>0$ is consistent with the productivity-sharing hypothesis.

A rather different approach would be to assume that firms unilaterally determine working hours. In labour demand models distinguishing between workers and hours, there is a trade-off between the extensive margin - the number of workers - and the intensive margin - the number of hours worked per worker. As long as fixed costs per worker exist, an increase in hourly wage costs leads to a relative cost increase for the intensive margin, reducing optimal demand for hours $h^{d}$, see e.g. Hart (1984). In a log-linear specification, this leads to the following simple demand for hours

$$
h^{d}=\alpha_{0}-\alpha_{w} w_{c}+\alpha_{x}^{\prime} x_{d}
$$

The demand for hours depends negatively on wage costs $w_{c}$, and not on net real wages $w_{n}$ as in the labour supply model (2) or the monopoly union hours equation (3). The vector $x_{d}$ captures other factors that may influence the demand for hours, such as factor prices like the user costs of capital, and non-neutral technical progress.

Finally, a bargaining model of hours would combine the determinants included in the monopoly union model (3) and the labour demand model (4). This yields the generic log-linear model

$$
h=\alpha_{0}-\alpha_{w} w_{c}+\alpha_{b} b-\alpha_{u} u+\alpha_{s} s+\alpha_{x}^{\prime} x
$$


By an appropriate choice of the $\alpha$-parameters and forcing variables in $x$, this equation encompasses all three previous models. Due to data limitations the forcing variables will be ignored in the empirical application. The monopoly union model (3) then leads to the restrictions $\alpha_{s}=\alpha_{w}$, as net wages determine hours in that case. Further omitting the outside option $\alpha_{b}=\alpha_{u}=0$ would yield the labour supply model (2). On the other hand, the joint restrictions $\alpha_{b}=\alpha_{u}=\alpha_{s}=0$ give the labour demand model of equation (4). Kapteyn et al. (2004) include the hourly before tax earnings and the employment rate in their cross-country study. This is another mixture of the above models. Their corresponding estimates are $\alpha_{w}=0.11$ and $\alpha_{u}=-0.01$.

\subsection{Reduced form}

Equations (1) and (5) jointly determine hourly wages and working time, at given productivity, benefit levels, unemployment and wedge. To focus on the work-sharing versus productivitysharing hypotheses, consider the following reduced form elasticities of working time with respect to productivity and unemployment

$$
\begin{aligned}
& \frac{d h}{d a_{h}}=-\frac{\alpha_{w} \gamma_{a}}{1-\alpha_{w} \gamma_{h}}<0 \\
& \frac{d h}{d u}=-\frac{\alpha_{u}-\alpha_{w} \gamma_{u}}{1-\alpha_{w} \gamma_{h}}
\end{aligned}
$$

where $\alpha_{w} \gamma_{h}<1$ is assumed to hold. This assumption implies that the downward sloping (in terms of hours) wage equation is flatter than the backward bending hours equation. This is obviously the case when hours would be inelastic with respect to wages.

An increase in hourly productivity directly affects wage setting (1), but does not directly influence working time in (5). Given the expected signs of the parameters, $\alpha_{w}>0$ and $\gamma_{h}>0$, the induced increase in wages reduces hours worked, which in turn may lead to an additional pressure on hourly wages. As a result, hourly wages increase more than the initial impact $\gamma_{a}$ and working hours decline more. So the model supports the productivity-sharing hypothesis that increased productivity leads to reductions in working time.

An increase in unemployment has a direct impact both on wage setting and hours determination: wages are moderated $\left(\gamma_{u}>0\right)$ and hours worked are reduced due to the worksharing motive $\left(\alpha_{u}>0\right)$. The indirect effects, however, work exactly in the opposite directions. The wage moderation leads to an upward pressure on hours worked (if $\alpha_{w}>0$ ), whereas the initial reduction in hours through the work-sharing motive leads to an upward pressure on hourly wages (if $\gamma_{h}>0$ ). The final impact is ambiguous for both hours and hourly wages. Whether the work-sharing hypothesis holds is thus an empirical matter.

\section{Data and estimation procedure}

The model was estimated with annual data for 1960-1997 for the Dutch market sector. The last two years have been retained to test for predictive failure. The sources are briefly described in the Data Appendix. The development of the main variables has been outlined in Section 2. 
Table 3 gives time series properties of the data. All but one series appear to have unit roots. ${ }^{7}$ Most series are I(1), although real wage costs $w_{c}$ seem to be I $(2) .{ }^{8}$ Given the low power of unit root tests in small samples, however, the impression is that this is due to the rather short sample period. Moreover, net real wages $w_{n}$ and the wedge $s$ are both I(1), which would imply that their sum $\left(w_{c}\right)$ should also be I(1). Similarly, the labour share $\varphi_{N}$ and labour productivity per hours worked $a_{h}$ are I(1), so their sum - again corresponding to $w_{c}$ - should be I(1). Taken together, it thus seems reasonable to proceed as if real wage costs are $\mathrm{I}(1)$.

\section{[TABLE 3 ABOUT HERE]}

An alternative to the hypothesis of non-stationarity of our series could be that the series are stationary, but with structural breaks. The obvious candidates for such breaks could be the oil crises of the 1970s and 1980s or the Wassenaar Agreement of 1982. Experimenting with such breaks did not change the conclusion, however, that the variables appear to be nonstationary.

To account for the non-stationarity of the data, the model was estimated in errorcorrection form. This has the additional advantage of allowing flexible dynamics in the process of wage formation and hours determination, as the theories presented in the previous section have nothing to say about the dynamic adjustment path.

Before analysing the structural error correction model for wages and working time, I applied Johansen's procedure to test for the number of cointegrating relations in the system of six variables. A VAR of order 2 with constant and trend was specified. ${ }^{9}$ In order to exclude the possibility of a quadratic trend under the hypothesis of one or more unit roots, the linear trend was restricted to appear only in the cointegrating relations. Table 4 reports the two usual likelihood ratio statistics for cointegration, see Johansen and Juselius (1990).$^{10}$ Neither test statistic rejects the null hypothesis of three cointegrating relationships, whereas the null hypothesis of at most two relations is rejected: at a $1 \%$ significance level for the trace statistic and at $5 \%$ significance for the $\lambda_{\max }$ statistic. Accordingly there appear to be three cointegrating relations within the system of six variables.

\section{[TABLE 4 ABOUT HERE]}

\footnotetext{
${ }^{7}$ The only series that seems to be stationary is the difference between the replacement rate $\rho$ and the labour share $\varphi_{N}$. As both series individually are I(1), this suggests that both variables are cointegrated. The economic logic might be that higher benefits lead to higher taxes, leading in turn to an increase in the labour share, but this is speculative. Alternatively, a high labour share might increase the demands for relatively high benefits.

${ }^{8}$ There is some evidence in the literature that nominal wages and prices could be I(2), but relative prices, and thus real wages, are typically found to be I(1), see e.g. Banerjee et al. (2001).

${ }^{9}$ With annual data two lag's appear to be reasonable, but because of a lack of degrees of freedom I did not test for the number of significant lag's. But, as the unrestricted reduced form of the conditional model does not seem to be misspecified, see Table 5 in the next section, the number of lags included appear to be appropriate.

${ }^{10}$ The results were obtained using PcFiml 9.0, see Doornik and Hendry (1997).
} 
Since the main interest lies in modelling wages and working time - rather than in deriving empirical models for productivity, benefits, unemployment or the wedge - a conditional approach seems appropriate. ${ }^{11}$ Such an approach only yields valid inferences if the conditioning variables are weakly exogenous for the short-run and long-run parameters of the wage and working time model. This will be tested for.

Within the conditional model a maximum of two cointegrating relations can be identified, which will be identified as wage setting and hours determination, respectively. As there are three cointegrating relations within the system, no unique long-run relations can be found, however. Table 3 suggests that the third cointegrating relation may be that between the replacement rate and the labour share, as their difference is stationary. This involves five of the six variables of the system, with only the unemployment rate not included. This third relation could be used to eliminate the benefit level from the long-run cointegrating relations.

\section{Estimation results}

\subsection{Unrestricted reduced form}

As argued by Spanos (1990), the statistical adequacy of a structural model should be assessed by misspecification tests of the unrestricted reduced form (URF). The URF is the unrestricted model of $w_{c}$ and $h$, conditional upon $a_{h}, b, u$ and $s$. As with the VAR of the system, the maximal lag length was a priori set to 2 . A constant and a trend were also included. The trend may capture the omitted exogenous variables in the model, especially in the hours equation. It is highly significant in the URF-model, with a p-value of 0.006. Including other explanatory variables failed to get rid of the trend. In particular, the share of female employment, the incidence of part-time employment and a crude measure for quasi-fixed labour costs were used. The first two variables were intended to capture changes in preferences, the latter variable should influence the demand for hours. Neither variable had a significant effect.

Table 5 provides some statistics for the two reduced form equations. There is clear evidence of first-order auto-correlation in the wage equation. However, transforming the dependent variable from hourly wages $w_{c}$ to annual wages $w_{c}+h$ (see the third column of the table), seems to solve this problem. This suggests that the auto-correlation problem is an artefact of the contemporaneous interaction between wage setting and hours determination, which will be taken into account in the structural model. ${ }^{12}$ So no further lags were needed to avoid autocorrelation. None of the other diagnostic tests indicate misspecification at the $5 \%$ significance level.

[TABLE 5 ABOUT HERE]

\footnotetext{
${ }^{11}$ See Urbain (1995) for a discussion of the relative merits and pitfalls of modelling cointegrated systems in conditional or in full system models.

${ }^{12}$ Moreover, the negative correlation $\hat{\rho}$ between the residuals of the two equations of the model almost vanishes when $w_{c}$ is replaced by $w_{c}+h$.
} 
The table also includes the Lagrange-multiplier test suggested by Boswijk and Urbain (1997) for weak exogeneity of the regressors for the long-run parameters (LMC). It tests the significance of the lagged error-correction errors of the URF in the marginal model of the conditioning variables and is not significant. ${ }^{13}$ Accordingly, the conditional approach can be used to provide valid inference on the long-run parameters.

\subsection{Identification}

The next step in the analysis is the specification of a just-identified structural model (JID). As illustrated by Johansen and Juselius (1994), this includes identification of the long-run and the short-run structure. To start with the latter, Table 5 indicates that the contemporaneous interaction between hourly wage setting and hours determination may be an important issue. There are several possibilities: at one extreme, wages may be set with predetermined working hours, which would imply that current hours $h_{t}$ influence current wages $w_{c t}$, but not vice versa; at the other extreme, current hours are set with predetermined hourly wages in labour supply models, which would imply that current net real wages $w_{n t}$ influence hours $h_{t}$, but not vice versa. Many intermediate positions are possible. The just-identified model allows for interactions in both directions, which requires other identifying restrictions for the dynamics. As there does not seem to be any theoretical reason to pick a particular (lagged) variable, the least significant lagged differenced variables in the URF was used. As a consequence, the lagged change in hours in the wage equation and the lagged change in unemployment in the hours equation were omitted for identification purposes. Using different short-run identification restrictions yielded the same parsimonious results.

A diagonal error-correction matrix was used to identify the long-run parameters in the JID. This does not provide any structural interpretation, but allows for a simple test of nocointegration (WNC). This is a Wald-test for the joint occurrence of the lagged levels (the errorcorrection terms) in each individual equation. Under the null-hypothesis of no-cointegration the distribution of the test is non-standard, but Boswijk (1994) has calculated critical values. ${ }^{14}$

Table 6 gives the results for the JID-model, estimated by FIML. For notational economy, the table does not report the short-run dynamics, but only the cointegrating relations and the corresponding diagonal error-correction terms. The standard errors of the cointegrating vectors are calculated using the methods given in Bårdsen (1989). The no-cointegration tests give mixed results. For the hours equation, the WNC statistic is significant at the $1 \%$ level, rejecting the null-hypothesis of no-cointegration. This is confirmed by a Dickey-Fuller statistic (CDF) on the cointegrating vector. For the wage equation, however, the WNC is only significant at the $10 \%$ level. On the other hand, the CDF statistic suggests that the cointegrating vector is stationary. ${ }^{15}$

\section{[TABLE 6 ABOUT HERE]}

\footnotetext{
${ }^{13}$ The marginal system is modelled as an unrestricted VAR of the four conditioning variables with 2 lags, a constant and a trend.

14 Boswijk (1994) calls WNC an instability test, but to avoid confusion I prefer to call it a nocointegration test. The $\xi_{\tau}^{*}$-statistic was used to account for the trend in the model. With 4 exogenous variables, the $10 \%, 5 \%$ and $1 \%$ critical values are $20.76,23.33$ and 28.51 , respectively.

${ }^{15}$ A more or less similar ambiguity of the no-cointegration test statistics can be found in the URF of Table 5.
} 
The ambiguous results for the cointegration of the wage equation may be due to the inclusion of the trend in the equation. Single equation estimates of Dutch wage equations, see for example Broer et al. (2000), Broersma and Den Butter (2002) and Muysken et al. (1999), suggest that wages are indeed cointegrated with the variables included in here, but that no trend is needed. The parameter estimates of the cointegrating vector for wages in the JID even correspond fairly closely to the results found elsewhere: wages increase with productivity and benefits, their joint impact being proportional; ${ }^{16}$ wages decrease with unemployment, the semielasticity being around -1 ; and tax shifting is rather strong. In view of this, the results of Tables 6 and 7 are taken as evidence for the occurrence of two cointegrating relations in the constrained model.

\subsection{Parsimonious specification}

The next step was to identify structural long-run relations in the constrained model. In line with equations (1) and (5), the following parameterisation was used for the coingrating vectors: ${ }^{17}$

$$
\begin{aligned}
& z_{w}=w_{c}-\left[\gamma_{0}-\gamma_{h} h+\gamma_{a} a_{h}+\gamma_{b} b-\gamma_{u} u+\gamma_{s} s\right] \\
& z_{h}=h-\left[\alpha_{0}-\alpha_{w} w_{c}+\alpha_{b} b-\alpha_{u} u+\alpha_{s} s+\alpha_{t} t\right]
\end{aligned}
$$

The first cointegrating vector $z_{w}$ is interpreted as wage setting, therefore the coefficient on wages is normalised to one and the identifying restriction is that the trend is excluded. The second cointegrating vector $z_{h}$ is interpreted as hours determination, accordingly the coefficient on hours is normalised to one and, in line with equation (5), the identifying restriction is that productivity is excluded. As a consequence, the error-correction matrix is no longer diagonal in the structural model.

Table 7 presents the final estimation results of the structural model. It is a parsimonious specification that cannot be rejected against the URF, the p-value of the likelihood-ratio test for the 20 parameter restrictions being 0.238 . The no-cointegration tests of the model indicate that there are indeed two different cointegrating vectors. Both series show deviations of the actual values relative to their long-run targets of at most $4 \%$ in absolute value, their correlation coefficient is 0.48 .

\section{[TABLE 7 ABOUT HERE]}

According to the cointegrating relation for wages $z_{w}$, wage costs are proportional to the aspiration levels, given by a weighted average of productivity $(64 \%)$ and benefits (the remaining

\footnotetext{
${ }^{16}$ When the replacement rate instead of benefit level is included, as in Broer et al. (2000), wages are proportional to productivity.

${ }^{17}$ As the system of six variables contains three cointegrating relations, the two cointegrating relations of the constrained structural model are not uniquely identified.
} 
$36 \%){ }^{18}$ The long-run semi-elasticity of unemployment on wages is around -1 and the tax elasticity of wages is 0.6 . Given the small standard error of the latter estimate, the tax burden is shared by both sides of the market in the long run. The impact of working time on hourly wages appears to be negative, although not significant (p-value 0.164). The results do reject that the long-run wage equation can be written in annual terms, the p-value of the restriction $\gamma_{h}=1-\gamma_{a}$ being 0.035 . Hence the usual Dutch wage equations seem to be misspecified. The results presented here indicate that in the long run reduced working time leads at most to a small increase in hourly wages, but certainly not sufficient to keep annual remuneration constant. So working time reduction unambiguously leads to wage moderation in terms of annual remuneration. ${ }^{19}$

According to the cointegrating relation for hours $z_{h}$, wages have a strong negative impact on normal hours, the elasticity being almost 1 . However, as the wedge has only a much smaller positive impact, the long-run hours equation can not be written in terms of net wages only. The long-run hours equation thus combines supply and demand factors with roughly equal weights: the elasticity with respect to net wages being 0.44 and with respect to wage cost being -0.52 (= 0.44-0.96). Real benefits have a strong positive impact of hours worked in the long run. This is consistent with the role of unions in hours determination, see equation (3). However, in that case hours determination should also incorporate the work-sharing argument. But no significant role is found for unemployment in the cointegrating relation for hours in Table 7, the p-value of the imposed restriction $\alpha_{u}=0$ being $0.674 .{ }^{20}$ Finally, the cointegrating relation for hours includes a significant trend. In terms of a labour supply interpretation, this would essentially mean a shift of preferences towards longer hours. This seems rather unlikely, although one could argue that the increased opportunities of part-time work allowed the over-employed individuals to switch from full-time to part-time jobs. To test this hypothesis, the incidence of part-time employment and the share of female employment were included as explanatory variables, but without any success. An alternative interpretation of the trend comes from labour demand. A change in technology or a change in relative costs could also shift the demand for hours. A rough measure of quasi-fixed labour costs was included, but again without success. Further research in this direction is needed.

The error-correction matrix is triangular in the structural model. The lagged cointegrating vector for wages $z_{w}$ has an expected negative impact on the growth of wages, but has a positive effect on the growth of working time. The error-correction of hours $z_{h}$ only affects the growth in working time negatively. ${ }^{21}$ The size of the own error-correction coefficients illustrates that wages adjust more quickly to disequilibrium than hours. This seems in accordance with the notion that bargaining over working time is not always on the agenda. Alternatively, it could be that social norms play an important role in the adjustment of hours worked, see e.g., Bentivogli (1992) and De Neubourg and Vendrik (1994).

\footnotetext{
${ }^{18}$ The p-value of the likelihood-ratio test of the restriction that both coefficients in the cointegrating wage vector sum to one is 0.896 .

${ }^{19}$ To test the possible U-shape between hourly wages and hours worked, lagged hours squared was added as an additional explanatory variable. This did not improve the fit, however.

${ }^{20}$ Moreover, when included in $z_{h}$, unemployment has the wrong sign.

${ }^{21}$ The $\mathrm{p}$-value for the imposed restriction that $z_{h t-1}$ does not affect the wage equation is 0.114 .
} 
The sign of $z_{w}$ in the hours equation is slightly puzzling, as it works in the opposite direction of the negative long-run impact of wages on hours. A possible explanation may be the intertemporal substitution hypothesis. When hourly wages temporarily exceed the long-run target, it may pay to increase hours temporarily above its own target level, even though the long-run elasticity of hours with respect to wages is negative. Combining the effects of both error-correction terms in the hours equation, lagged wages have a small negative impact on the growth of working time $\left(-0.186=0.280-0.485^{*} 0.962\right)$.

Finally, consider the dynamic adjustment of the parsimonious model. To derive valid inference for the short-run dynamics, weak-exogeneity requires the regressors and the disturbances to be orthogonal, see Boswijk and Urbain (1997). This is tested by adding the residuals of the marginal system of the conditioning variables to the structural model. This variable addition test (LMO) is not significant (p-value 0.161). Thus, the orthogonality restriction cannot be rejected and inference on short-run dynamics is valid.

Wage growth is directly affected by the growth in productivity, benefits and the wedge. These estimates corresponded rather closely to the corresponding coefficients in the cointegrating vector for wages multiplied by the error-correction coefficient. Testing for this joint hypothesis gave a p-value of 0.804 . Therefore, this restriction on the short-run dynamics of the wage equation in the parsimonious model was imposed in the specification of Table 7.

Although the cointegrating wage relation is specified in hourly terms, the dependent variable in the dynamic equation is the annual wage growth. The restriction imposed on the coefficient for the growth in working time is accepted, with a p-value of $0.205 .^{22}$ Notice, however, that the wage equation also includes the growth of annual productivity as an explanatory variable. ${ }^{23}$ Looking at the impact of a reduction in hours, this means that in the short-run annual remuneration is only reduced insofar as annual productivity is reduced. In other words, hourly wages tend to increase almost proportionally in the short run. The long-run effects discussed earlier showed, however, that in the long run hourly wages increase significantly less than proportional and may even remain constant.

Changes in working hours are endogenous in the model, though, and adjustments in hours take a long time according to the estimates of the hours equation in Table 7. Again, this may be explained by social norms and habits. The negative sign of the lagged growth of hours, suggests that the adjustment path is oscillating, but to analyse the dynamic adjustment we should look at the whole system. ${ }^{24}$ The growth in working time reacts negatively to the contemporaneous increase in net real wages, although the impact is much smaller than in the long run. ${ }^{25}$ So, whereas in the long-run labour supply and demand factors jointly affect full-time hours, labour

\footnotetext{
${ }^{22}$ The alternative hypothesis that the coefficient of $\Delta h$ equals 0 , instead of -1 , is strongly rejected, with a p-value of 0.0003 against a free estimate of that coefficient.

${ }^{23}$ Alternatively, the growth rate of hourly productivity could have been included, instead of the growth rate of annual productivity. This gives rather similar results, the log-likelihood being slightly higher (363.848). On the other hand, the correlation between the residuals of equations increases to 0.347 in this alternative specification.

${ }^{24}$ The characteristic roots of the parsimonious system are $0.682,-0.427,0.271$ and 0 . The system is thus stable and oscillates.

${ }^{25}$ The p-value for the imposed restriction on $\Delta s_{t}$ is 0.654 . Accordingly, the dynamic adjustment can indeed be specified in terms of the growth of net real wages.
} 
supply effects appear to dominate in the short run. Finally, the innovation in real benefits increases the growth rate of hours. Unfortunately, it is hard to find any interpretation for this result.

\section{Work-sharing or productivity-sharing}

The estimation results can be used to consider the determinants of the Dutch full-time working time in more detail. Table 8 gives the implied long-run reduced form elasticities for wages and hours worked. For hours worked the table contains the empirical counterpart of the elasticities presented in equations (6) and (7).

\section{[TABLE 8 ABOUT HERE]}

The wage elasticities with respect to the exogenous variables are roughly in line with the cointegrating relation $z_{w}$ identified in Table 7 . The reason is that the estimated coefficient for hours $\gamma_{h}$ in the wage equation (1) is rather small, so interaction effects via the hours equation (5) are almost negligible. The small negative decline of $0.2 \%$ a year is due to the trend in the hours equation, however.

For full-time hours, the reduced form elasticities are a mixture of the effects identified in the hours and wage equations, often with opposite signs. Consistent with the productivitysharing hypothesis, there is a clear negative impact of productivity. This is due to the negative elasticity of working time with respect to wages, combined with the impact of productivity on wages. Partly offsetting this is the positive effect of the trend in the hours equation. An increase in benefits has a similar negative effect via the wage equation as an increase in productivity, but this indirect effect is dominated by the positive direct effect in hours determination. With respect to unemployment, no evidence for the work-sharing hypothesis was found in the structural model. Accordingly, there is only an indirect effect via the wage equation, leading to a positive instead of negative reduced form elasticity. As unemployment reduces wages, there is a upward pressure on hours. For the wedge, the direct and indirect effects work in opposite directions, and the indirect effect via wages appears to dominate. Finally, the positive effect of the trend is determined by its direct impact on hours. As the implied increase in hours reduces hourly wages in the wage equation, this feeds back to even longer hours in the hours equation.

These estimated long-run reduced form elasticities reinforce the conclusion from the Granger causality tests in Table 2: the reduction in Dutch full-time hours should be entirely attributed to productivity-sharing, whereas work-sharing did not play any significant role.

Combining the elasticities on hourly wages and hours worked, the third row of Table 8 gives the impact on annual remuneration. The surprise may be that productivity and unemployment have rather weak effects, as the impact on $w_{c}$ and $h$ roughly cancel out.

\section{Summary and conclusions}

The starting point for this paper was the observation that full-time working hours have steadily declined in the Netherlands. The two main hypotheses put forward for this behaviour are worksharing and productivity-sharing. In the former, one would expect hours to decline in times of high unemployment, whereas in the latter productivity induced wage growth is the transmission channel. The paper develops a simple empirical model to assess the importance of both 
hypotheses. The joint model for wages and working time is estimated using cointegration techniques to account for the non-stationarity of the data.

Two cointegrating relations were identified in the data, which can be interpreted as wage setting and the hours determination, respectively. The wage equation is quite consistent with earlier work on Dutch wage equations, the novelty being that wage models specified in annual terms seem to be misspecified. Indeed, full-time hours only appear to have a weak negative impact on hourly wages in the long run. So a reduction in working hours leads to a significant decline in total remuneration.

The hours equation is not consistent with a simple labour supply model, but also seems to incorporate union (benefits) and labour demand (wage costs) effects. With respect to the determinants of working time, the estimates provide evidence that the work-sharing hypothesis does not hold. The decline in hours is mainly driven by increases in hourly wages (and hourly wage costs), and thus by productivity-sharing.

Future work in the determination of hours and the interaction with wage determination is needed. If full-time hours are not solely determined by labour supply considerations, as suggested by the present analysis, alternative models are needed to investigate its determinants. From an empirical perspective, this may allow us to dispose of the rather unsatisfactory trend in the current empirical specification. Furthermore, it stresses that labour supply models should take hours restrictions into account. Another strand of research may be to explain the different levels of hours in a cross-country study. Blanchard (2004) identifies these differences as one of the important differences between the US and Europe.

Another extension to the model would be to incorporate labour demand for workers or price setting in the analysis. This would strengthen the relation between the demand side and hours determination. Moreover, it would provide the opportunity to analyse in more detail the relation between working time and employment or unemployment.

\section{Acknowledgement}

I am grateful to Joan Muysken and Bertrand Candelon for useful comments on earlier versions of this paper.

\section{References}

Banerjee, A., L. Cockerell and B. Russel (2001), An I(2) analysis of inflation and markup, Journal of Applied Econometrics, vol. 16 (3), pp. 221-240.

Bårdsen, G. (1989), Estimation of Long Run Coefficients in Error Correction Models, Oxford Bulletin of Economics and Statistics, vol. 51 (3), pp. 345-350.

Bentivogli, C. (1992), Time allocation and economic welfare, Labour, vol. 6 (2), pp. 105-122.

Blanchard, O. (2004), The Economic Future of Europe, Journal of Economic Perspectives, forthcoming.

Boswijk, H.P. (1994), Testing for an unstable root in conditional and structural error correction models, Journal of Econometrics, vol. 63 (1), pp. 37-60.

Boswijk, H.P. and J.-P. Urbain (1997), Lagrange-multiplier tests for weak exogeneity: a synthesis, Econometric Reviews, vol. 16 (1), pp. 21-38. 
Broer, D.P., D.A.G. Draper and F.H. Huizinga (2000), The equilibrium rate of unemployment in the Netherlands, De Economist, vol. 148 (3), pp. 345-371.

Broersma, L. and F.A.G. den Butter (2002), An explorative empirical analysis of the influence of labour flows on wage formation, Applied Economics, vol. 34 (13), pp. 1583-1592.

Broersma, L., J. Koeman and C. Teulings (2000), Labour supply, the natural rate, and the welfare state in the Netherlands: the wrong institutions at the wrong point in yime, Oxford Economic Papers, vol. 52 (1), pp. 96-118.

Calmfors, L. (1985), Work sharing, employment and wages, European Economic Review, vol. 27 (3), pp. 293-309.

De Neubourg, C. (1991), Where have all the hours gone? Working time reduction policies in the Netherlands, in: K. Hinrichs, W.K. Roche and C. Sirianni (eds.), Working time in transition: The political economy of working hours in industrial nations, Philadelphia: Temple University Press, pp. 129-147.

De Neubourg, C. and M. Vendrik (1994), An extended rationality model of social norms in labour supply, Journal of Economic Psychology, vol. 15 (1), pp. 93-126.

Dickens, W.T. and S.J. Lundberg (1993), Hours restrictions and labor supply, International Economic Review, vol. 34 (1), pp. 169-192.

Doornik, J.A. and D.F. Hendry (1997), Modelling dynamic systems using PcFiml 9.0 for windows, London: International Thomson Business Press.

Drèze, J. (1986), Work-sharing, Economic Policy, vol. 3, pp. 562-619.

Dur, R.A.J. (2001), Explaining unemployment trends in the Netherlands, Journal of Policy Modeling, vol. 23 (2), pp. 161-168.

Freeman, R.B. (1998), Work-Sharing to Full Employment: Serious Option or Populist Fallacy?, in: R.B. Freeman and P.Gottschalk (eds.), Generating Jobs, How to Increase Demand for Less-Skilled Workers, New York: Russell Sage Foundation, vol. 6, pp. 195-222.

Graafland, J.J. and F.H. Huizinga (1999), Taxes and benefits in a non-linear wage equation, De Economist, vol. 147 (1), pp. 39-54.

Hart, R.A. (1984), Worksharing and factor prices, European Economic Review, vol. 24 (2), pp. $165-188$.

Hartog, J. (1999), Wither Dutch corporatism? Two decades of employment policies and welfare reforms, Scottish Journal of Political Economy, vol. 46 (4), pp. 458-487.

Hunt, J. (1998), Hours reductions as work-sharing, Brookings Papers on Economic Activity, vol. 1998 (1), pp. 339-381.

Hunt, J. (1999), Has work-sharing worked in Germany?, The Quarterly Journal of Economics, vol. 114 (1), pp. 117-148.

Ilmakunnas, P. (1995), Working time and labour demand in Finnish manufacturing: short-run and long-run effects, Applied Economics, vol. 27 (10), pp. 995-1002.

Jacobson, T. and H. Ohlsson (2000), Working time, employment, and work sharing: Evidence from Sweden, Empirical Economics, vol. 25 (1), pp. 169-187.

Johansen, S. and K. Juselius (1990), Maximum likelihood estimation and inference on cointegration - With applications to the demand for money, Oxford Bulletin of Economics and Statistics, vol. 52 (2), pp. 169-210.

Johansen, S. and K. Juselius (1994), Identification of the long-run and the short-run structure; An application to the IS-LM model, Journal of Econometrics, vol. 63 (1), pp. 7-36. 
Kapteyn, A., A. Kalwij and A. Zaidi (2004), The myth of worksharing, Labour Economics, vol. 11 (3), pp. 293-313.

Layard, R., S. Nickell and R. Jackman (1991), Unemployment, macroeconomic performance and the labour market, Oxford: Oxford University Press.

Marimon, R. and F. Zilibotti (2000), Employment and distributional effects of restricting working time, European Economic Review, vol. 44 (7), pp. 1291-1326.

Muysken, J. A.P. van Veen and E.R. de Regt (1999), Does a shift in the tax burden create employment?, Applied Economics, vol. 31 (10), pp. 1195-1205.

Osberg, L. and S. Phipps (1993), Labour supply with quantity constraints: estimates from a large sample of Canadian workers, Oxford Economic Papers, vol. 45 (2), pp. 269-291.

Spanos, A. (1990), The simultaneous-equations model revisited: statistical adequacy and identification, Journal of Econometrics, vol. 44 (1-2), pp. 88-105.

Tummers, M. and I. Woittiez (1991), A simultaneous wage and labor supply model with hours restrictions, Journal of Human Resources, vol. 26 (3), pp. 393-423.

Urbain, J.-P. (1995), Partial versus full systems modelling of cointegrated systems, An empirical illustration, Journal of Econometrics, vol. 69 (1), pp. 177-210.

Van Doorne-Huiskes, A. and W. de Lange (1994), Netherlands, in: G. Bosch, P. Dawkins and F. Michon (eds.), Times are Changing, Geneva: ILO, pp. 229-245.

\section{Appendix}

The main source of the data is the so-called long macro series (1948-1995) of the Netherlands Bureau for Economic Policy Analysis CPB, updated with the data available in their annual survey, Centraal Economisch Plan. These data are among others based on the National Accounts of Statistics Netherlands. When necessary, growth rates are used to deal with the breaks in the National Accounts series. The data are available on request. 
Figure 1

Full-time working hours

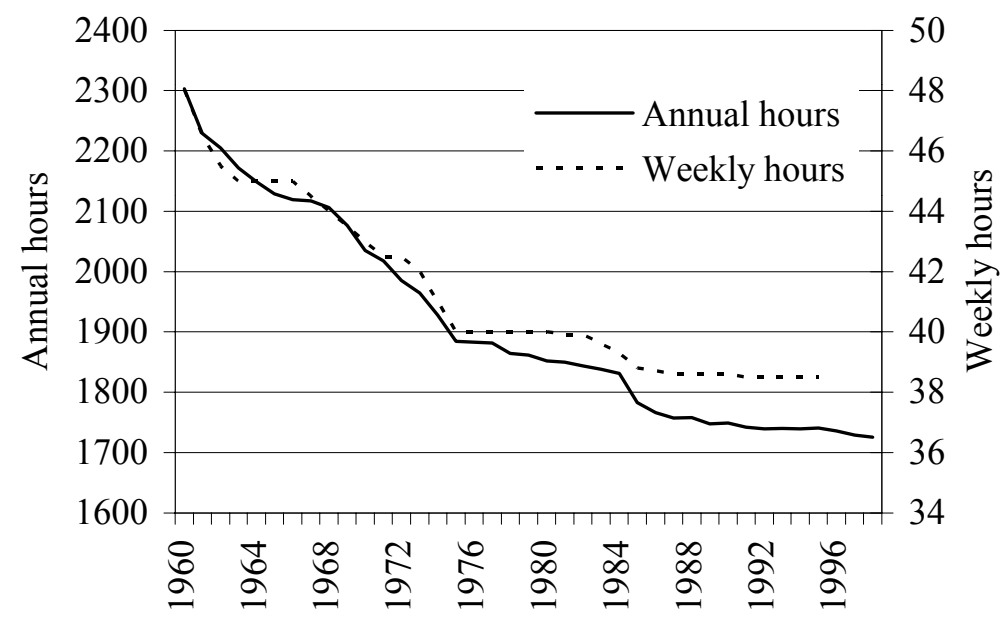




\begin{tabular}{lccccc}
\hline & $1960-1995$ & $1960-1973$ & $1974-1995$ & $1974-1982$ & $1983-1995$ \\
\hline \multirow{5}{*}{$H_{c}$} & -0.8 & -1.2 & -0.6 & -0.7 & -0.5 \\
$W_{c}$ & 4.4 & 7.5 & 2.4 & 4.0 & 1.3 \\
$W_{n}$ & 2.7 & 5.0 & 1.3 & 1.3 & 1.3 \\
$A_{h}$ & 4.0 & 6.2 & 2.6 & 3.2 & 2.2 \\
& & & Levels & \\
$u$ & 4.4 & 1.1 & 6.5 & 4.0 & 8.2 \\
$\varphi_{N}$ & 73.9 & 69.3 & 76.8 & 81.3 & 73.6 \\
\hline
\end{tabular}




\begin{tabular}{lcccc}
\hline \multirow{2}{*}{$\begin{array}{l}\text { Endogenous } \\
\text { variable }\end{array}$} & \multicolumn{4}{c}{ Exogenous variables } \\
\cline { 2 - 5 } & $h$ & $a_{h}$ & $u$ & joint \\
\hline$h$ & & $0.002^{* *}$ & 0.093 & $0.007^{* *}$ \\
& & {$\left[0.008^{* *}\right]$} & {$[0.444]$} & \\
$a_{h}$ & 0.610 & & 0.244 & 0.333 \\
& {$[0.456]$} & & {$[0.155]$} & \\
$u$ & 0.771 & 0.104 & & 0.253 \\
& {$[0.718]$} & {$[0.072]$} & & \\
\hline
\end{tabular}

p-values Granger causality test in tri-variate model, trend included; $p$-values bivariate Granger causality tests (trend included) between brackets. Significance levels: * at $5 \%$ and $* *$ at $1 \%$. 


\begin{tabular}{|c|c|c|c|c|c|c|c|}
\hline \multirow{3}{*}{$\begin{array}{l}\text { Variable } x \\
h\end{array}$} & \multirow{2}{*}{\multicolumn{2}{|c|}{ Growth rate ${ }^{a}$}} & \multicolumn{5}{|c|}{$\mathrm{ADF}^{\mathrm{b}}$} \\
\hline & & & \multicolumn{2}{|c|}{$x$} & \multicolumn{2}{|c|}{$\Delta x$} & \multirow[t]{2}{*}{$\Delta^{2} x$} \\
\hline & -0.007 & $(0.007)$ & -0.21 & {$[\mathrm{t}, 0]$} & $-4.71 * *$ & {$[\mathrm{c}, 0]$} & \\
\hline$w_{c}$ & 0.041 & $(0.032)$ & -1.39 & {$[\mathrm{t}, 3]$} & -0.86 & {$[\mathrm{c}, 2]$} & $-7.85^{* *} \quad[\mathrm{n}, 1]$ \\
\hline$w_{n}=w_{c}-s$ & 0.024 & $(0.029)$ & -1.64 & {$[\mathrm{t}, 0]$} & $-3.42^{*}$ & {$[\mathrm{c}, 0]$} & \\
\hline$a_{h}$ & 0.038 & $(0.024)$ & -0.29 & {$[t, 0]$} & $-3.00^{*}$ & {$[\mathrm{c}, 0]$} & $-7.14 * * \quad[\mathrm{n}, 2]$ \\
\hline$b$ & 0.019 & $(0.041)$ & -1.34 & {$[\mathrm{t}, 0]$} & $-3.49^{*}$ & {$[\mathrm{c}, 0]$} & \\
\hline$u$ & 0.002 & $(0.007)$ & -0.86 & {$[\mathrm{c}, 2]$} & $-4.47 * *$ & {$[\mathrm{n}, 1]$} & \\
\hline$S$ & 0.017 & $(0.025)$ & -1.62 & {$[\mathrm{c}, 0]$} & $-3.00 * *$ & {$[\mathrm{n}, 0]$} & \\
\hline$\varphi_{N}=w_{c}-a_{h}$ & 0.003 & $(0.023)$ & -1.94 & {$[\mathrm{c}, 0]$} & $-4.86^{* *}$ & {$[\mathrm{n}, 0]$} & \\
\hline$\rho=b-w_{n}-h$ & 0.002 & $(0.027)$ & -1.55 & {$[\mathrm{c}, 0]$} & $-5.15^{* *}$ & {$[\mathrm{n}, 0]$} & \\
\hline$\rho-\varphi_{N}$ & -0.001 & $(0.028)$ & $-4.01 * *$ & {$[\mathrm{c}, 0]$} & & & \\
\hline
\end{tabular}

${ }^{\mathrm{a}}$ Standard deviation between parentheses.

${ }^{\mathrm{b}}$ The characteristics of the (adjusted) Dickey-Fuller test statistic (ADF) are given between brackets $[\mathrm{z}, \#]: \mathrm{z}=\{\mathrm{n}, \mathrm{c}, \mathrm{t}\}$ indicates neither constant or trend, constant included or trend and constant included, respectively; \# corresponds to the number of significant lags included. Significant rejection of nonstationarity is indicated by asterisks (* at the 5\%-level and ** at the $1 \%$-level). 
Table $4 \quad$ Cointegration tests (1962-1995)

\begin{tabular}{ccc}
\hline $\mathrm{H}_{0}$ & Trace & $\lambda_{\max }$ \\
\hline $\mathrm{r} \leq 5$ & 5.255 & 5.255 \\
$\mathrm{r} \leq 4$ & 17.13 & 11.87 \\
$\mathrm{r} \leq 3$ & 38.06 & 20.93 \\
$\mathrm{r} \leq 2$ & $73.74^{* *}$ & $35.68^{*}$ \\
$\mathrm{r} \leq 1$ & $119.8^{* *}$ & $46.05^{* *}$ \\
$\mathrm{r}=0$ & $189.8^{* *}$ & $69.98^{* *}$ \\
\hline
\end{tabular}

Likelihood ratio tests defined in Johansen and Juselius (1990). Significance levels: * at $5 \%$ and $* *$ at $1 \%$. Trend included. 


\begin{tabular}{|c|c|c|c|}
\hline & \multicolumn{3}{|c|}{ Dependent variable (OLS) } \\
\hline & $\Delta w_{c}$ & $\Delta h$ & $\Delta\left(w_{c}+h\right)$ \\
\hline & \multicolumn{3}{|c|}{ Test statistics ${ }^{\mathrm{a}}$} \\
\hline$\hat{\sigma}(\mathrm{x} 100)$ & 1.000 & 0.370 & 0.921 \\
\hline RSS (x1000) & 1.599 & 0.220 & 1.188 \\
\hline PF'97 & $F(2,16)=1.68$ & $\mathrm{~F}(2,16)=0.42$ & $\mathrm{~F}(2,16)=1.86$ \\
\hline LMA & $\mathrm{F}(1,15)=10.77 * *$ & $\mathrm{~F}(1,15)=0.29$ & $F(1,15)=3.90$ \\
\hline $\mathrm{ARCH}$ & $F(1,14)=0.12$ & $F(1,14)=0.31$ & $\mathrm{~F}(1,14)=0.19$ \\
\hline NORM & $\chi^{2}(2)=0.58$ & $\chi^{2}(2)=2.02$ & $\chi^{2}(2)=0.82$ \\
\hline RESET & $F(1,15)=0.14$ & $F(1,15)=3.24$ & $F(1,15)=1.68$ \\
\hline WNC & 21.85 & $61.41 * *$ & 21.67 \\
\hline \multirow[t]{2}{*}{$\mathrm{CDF}$} & $-4.39 * *$ & $-4.05 * *$ & $-3.86^{* *}$ \\
\hline & \multicolumn{3}{|c|}{ Model test statistics ${ }^{\mathrm{b}}$} \\
\hline log-likelihood & \multicolumn{2}{|l|}{375.343} & 375.343 \\
\hline$\hat{\rho}$ & \multicolumn{2}{|l|}{-0.389} & -0.020 \\
\hline PF'97 & $\mathrm{F}(4,16)=1.32$ & \multicolumn{2}{|c|}{$\mathrm{F}(4,16)=1.32$} \\
\hline VLMA & $F(4,26)=2.08$ & \multicolumn{2}{|c|}{$F(4,26)=2.08$} \\
\hline VNORM & $\chi^{2}(4)=1.89$ & \multicolumn{2}{|c|}{$\chi^{2}(4)=2.84$} \\
\hline LMC & $F(8,38)=1.85$ & \multicolumn{2}{|c|}{$\mathrm{F}(8,38)=1.85$} \\
\hline
\end{tabular}

${ }^{a} \hat{\sigma}$ is the equation standard error; RSS is the residual sum of squares; PF'97 is a Chow test for parameter constancy up to 1997; LMA is a Lagrange-Multiplier test for first-order residual autocorrelation; ARCH is a Lagrange-Multiplier test for first-order autoregressive conditional heteroscedasticity; NORM is WinGive's normality test of the residuals; RESET is Ramsey's specification test; WNC is a Wald statistic for no-cointegration; CDF is a Dickey-Fuller test with constant but no trend for non-stationarity of the cointegrating vector. Significance levels test statistics: $*$ at $5 \%$ and $* *$ at $1 \%$.

${ }^{\mathrm{b}} \hat{\rho}$ is the correlation between the residuals; VLMA is a test for first-order residual vector autocorrelation; VNORM is WinGive's vector normality test of the residuals; LMC is a LM-test for weak exogeneity of the regressors for the long-run parameters. 
Table 6 Cointegration tests just-identified model (FIML, 1962-1995)

\begin{tabular}{|c|c|c|}
\hline & \multicolumn{2}{|c|}{ Dependent variable } \\
\hline & $\Delta\left(w_{c}+h\right)$ & $\Delta h$ \\
\hline & \multicolumn{2}{|c|}{ Cointegrating vectors $^{\mathrm{a}}$} \\
\hline$w_{c}$ & 1. & $\begin{array}{c}0.610 \\
(0.588)\end{array}$ \\
\hline$h$ & $\begin{array}{c}0.393 \\
(0.676)\end{array}$ & 1. \\
\hline$a_{h}$ & $\begin{array}{l}-0.824 \\
(0.342)\end{array}$ & $\begin{array}{c}0.119 \\
(0.507)\end{array}$ \\
\hline$b$ & $\begin{array}{c}-0.232 \\
(0.189)\end{array}$ & $\begin{array}{l}-0.546 \\
(0.232)\end{array}$ \\
\hline$u$ & $\begin{array}{c}1.182 \\
(0.619)\end{array}$ & $\begin{array}{l}-0.506 \\
(0.698)\end{array}$ \\
\hline$s$ & $\begin{array}{c}-0.588 \\
(0.117)\end{array}$ & $\begin{array}{l}-0.120 \\
(0.344)\end{array}$ \\
\hline \multirow[t]{3}{*}{ trend $(* 100)$} & $\begin{array}{c}0.576 \\
(0.602)\end{array}$ & $\begin{array}{l}-0.941 \\
(0.536)\end{array}$ \\
\hline & \multicolumn{2}{|c|}{ Error correction coefficients ${ }^{\mathrm{a}}$} \\
\hline & $\begin{array}{l}-1.158 \\
(0.380)\end{array}$ & $\begin{array}{l}-0.456 \\
(0.159)\end{array}$ \\
\hline & \multicolumn{2}{|c|}{ No-cointegration tests ${ }^{\mathrm{b}}$} \\
\hline WNC & 21.10 & $51.21 * *$ \\
\hline \multirow[t]{2}{*}{$\mathrm{CDF}$} & $-4.12 * *$ & $-3.30^{*}$ \\
\hline & \multicolumn{2}{|c|}{ Model test statistics $^{\mathrm{c}}$} \\
\hline$\hat{\sigma}(\mathrm{x} 100)$ & 0.933 & 0.367 \\
\hline$\hat{\rho}$ & \multicolumn{2}{|c|}{0.580} \\
\hline log-likelihood & \multicolumn{2}{|c|}{375.343} \\
\hline
\end{tabular}

${ }^{\mathrm{a}}$ Standard errors between parentheses.

${ }^{\mathrm{b}} \mathrm{WNC}$ is a Wald statistic for no-cointegration; CDF is a DickeyFuller test with constant but no trend for non-stationarity of the cointegrating vector. Significance levels test statistics: ${ }^{*}$ at $5 \%$ and $* *$ at $1 \%$.

c $\hat{\sigma}$ is the equation standard error and $\hat{\rho}$ is the correlation between the residuals. 
Table $7 \quad$ Parsimonious estimation results (FIML, 1962-1995)

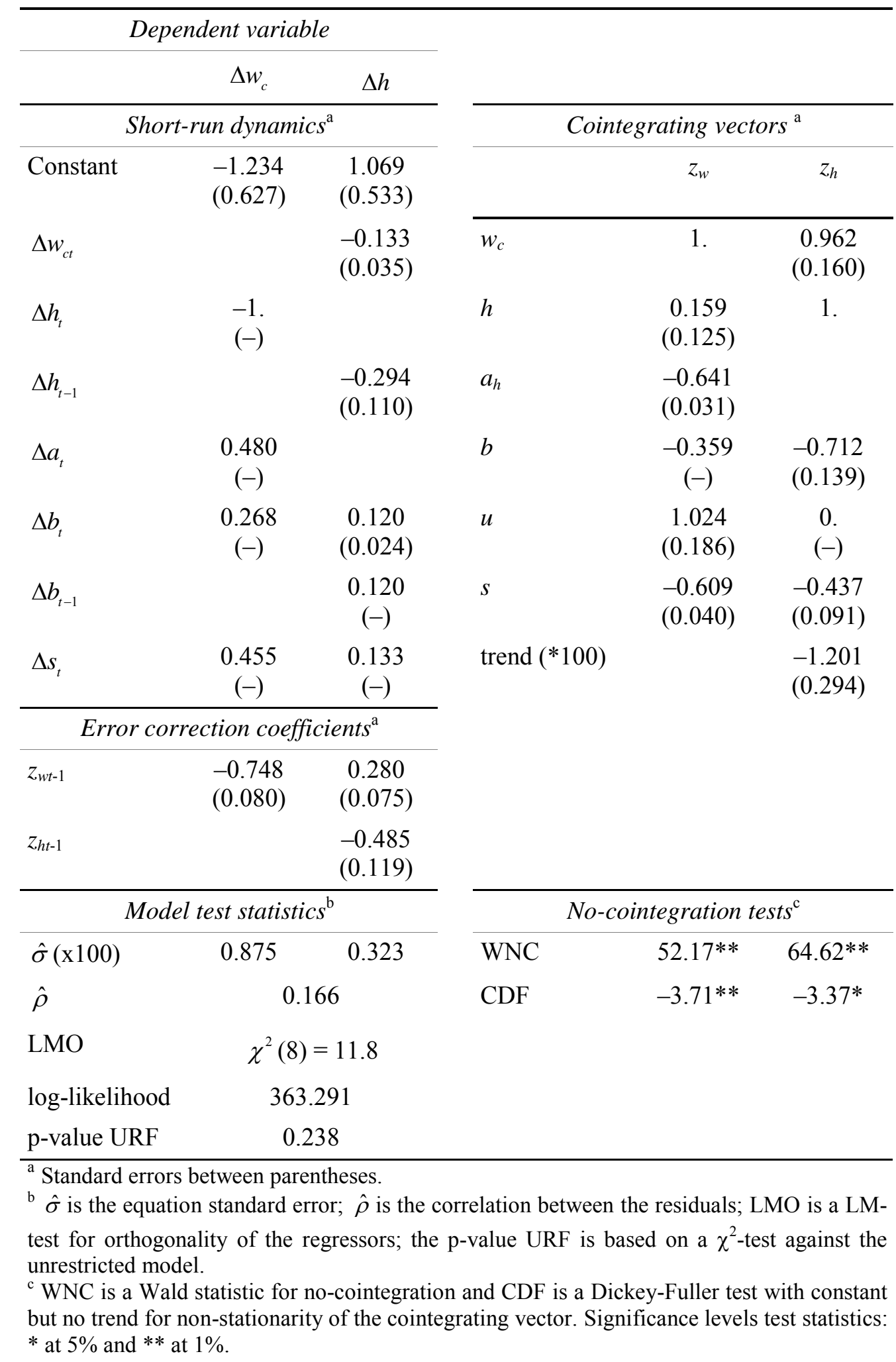


Table $8 \quad$ Long run reduced form elasticities

\begin{tabular}{lccrcc}
\hline & $a_{h}$ & $b$ & \multicolumn{1}{c}{$u$} & \multicolumn{1}{c}{$s$} & trend $(* 100)$ \\
\hline$w_{c}$ & 0.76 & 0.29 & -1.21 & 0.64 & -0.23 \\
$h$ & -0.73 & 0.43 & 1.16 & -0.18 & 1.42 \\
$w_{c}+h$ & 0.03 & 0.73 & -0.05 & 0.46 & 1.19 \\
\hline
\end{tabular}

